\title{
KANDUNGAN MIKROBA PATOGEN, RESIDU INSEKTISIDA ORGANOFOSFAT DAN LOGAM BERAT DALAM SAYURAN
}

\author{
Harsojo dan Sofnie M.Chairul
}

(Diterima tanggal: 2-Juni-2011; Disetujui tangal: 2-November-2011)

\begin{abstract}
The aim of this experiment is to know the pathogenic microbes, pesticide residue and heavy metals in raw vegetables (Lalab). The raw vegetables which used are string bean (Vigna sinensis), cabbage (Brassica oleraceae), cucumber (Cucumis sativa), and oregano (Ocimum basilicum L.). Those vegetables bought at traditional market and supermarket. Parameter measured are Salmonella contamination, total number of aerobic bacteria, total amount of coliform, and Staphylococcus. Another parameter are the pesticide residue and concentration level of lead,mercury and cadmium. Result of research shows the total aerob bacteria was in the range $3.50 \times 10^{4}$ and 3.70 $\times 10^{7} \mathrm{cfu} / \mathrm{g}$. The total coliform bacteria, and Staphylococcus in vegetables were in the range 0 and $1.29 \times 10^{7} ; 0$ and $1.2 .9 \times 10^{5} \mathrm{cfu} / \mathrm{g}$, respectively. No Salmonella was detected in all samples observed. Diazinon insecticide residue in string bean has exceeded in the normal level. The concentration of heavy metals were under allowable limit.
\end{abstract}

Keywords : vegetable, bacteria, insecticide residue and heavy metals.

\begin{abstract}
ABSTRAK
Tujuan penelitan ini ialah untuk mengetahui kandungan mikroba, residu pestisida dan logam berat yang terkandung dalam sayuran lalab. Sayuran yang diteliti terdiri dari kacang panjang (Vigna sinensis), kUBIS (Brassica oleraceae), ketimun (Cucumis sativa) dan kemangi (Ocimum basilicum L.). Sayuran yang dibeli dari pasar tradisional maupun swalayan ditanam pada media yang sesuai dengan parameter yang diamati. Parameter mikroba yang diamati ialah jumlah mikroba, koliform dan bakteri Staphylococcus serta kemungkinan adanya Salmonella. Disamping itu juga diamati residu pestisida dan kandungan logam berat seperti $\mathrm{Pb}, \mathrm{Hg}$ dan $\mathrm{Cd}$. Hasil penelitian menunjukkan kandungan bakteri aerob berkisar antara 3,50 × $10^{4}$ dan 3,70 × $10^{7} \mathrm{cfu} / \mathrm{g}$, untuk bakteri koli berkisar antara 0 hingga $1,49 \times 10^{7} \mathrm{cfu} / \mathrm{g}$ sedang untuk Staphylococcus berkisar antara 0 hingga $1,29 \times 10^{5} \mathrm{cfu} / \mathrm{g}$. Pada semua sayuran yang diteliti tidak ditemukan adanya Salmonella. Sayur kacang panjang pada lokasi III mengandung residu insektisida diazinon yang telah melebihi ambang batas. Logam berat yang diteliti pada semua sayuran masih dibawah ambang batas yang diizinkan.
\end{abstract}

Kata kunci: sayuran, bakteri, residu insektisida dan logam berat

\section{PENDAHULUAN}

Kasus keracunan makanan yang disebabkan adanya bakteri patogen di dalam bahan pangan dengan menimbulkan banyak korban yang meninggal dan ratusan orang yang perlu dirawat di rumah sakit sering terjadi di Indonesia. Adanya kasus keracunan makanan yang menelan banyak korban kurang mendapat perhatian yang serius mengenai penyebab keracunan pangan olahan non

daging maupun pangan yang terbuat dari bahan dasar daging. Di Indonesia kasus-kasus penyakit asal pangan, belum lengkap datanya, oleh karena itu kasus keracunan pangan disebut fenomena gunung es karena pangan dikonsumsi setidaknya tiga kali sehari $(1,2,3)$. Pada tahun 1997-2000 terjadi 65 Kejadian Luar Biasa (KLB) yang terdiri dari 7067 kasus dan 15 orang diantaranya meninggal. Pada

${ }^{1}$ Pusat Aplikasi Teknologi Isotop dan Radiasi, BATAN Jakarta, Jl. Pasar Jumat Keb. Lama Jakarta Selatan 12070, Telp. (021)7690709 Fax. (021) 7691607, Email: apuharsojo@yahoo.com 
tahun 2002 - 2003 terjadi lebih dari 10 kasus dan 1000 orang meninggal (3). Di Amerika, kasus keracunan makanan yang disebabkan oleh produk segar meningkat setiap tahunnya. Penyebab keracunan makanan yang mencakup beragam buah dan sayuran adalah bakteri Salmonella dan Escherichia coli 0157:H7 (3). Bakteri ini dianggap sebagai suatu agen infeksi karena bersifat toksigenik dan sangat berguna sebagai indikator kontaminasi fekal ${ }^{(4)}$. Bakteri ini bersumber dari tanah, air, manusia, hewan peliharaan (kucing, babi, sapi, unggas) dan sumber lainnya ${ }^{(2)}$. Menurut Ratih ${ }^{(1)}$, di negara maju yang mempunyai sanitasi sangat tinggi masih dilaporkan bakteri patogen sebagai penyebab utama kasus penyakit asal pangan. Indonesia sebagai negara berkembang yang sanitasinya masih dibawah negara maju, kemungkinan besar patogen asal pangan (foodborne pathogen) akan mendominasi. Di Indonesia banyak kasus diare ringan tidak dilaporkan, bahkan oleh sekelompok masyarakat diare dianggap bukan sebagai penyakit dan mereka akan mengobati sendiri. Padahal diare dapat berakibat fatal, misalnya tifus, kolera dan lain sebagainya. Beberapa bakteri patogen dapat menimbulkan penyakit di organ tubuh lainnya disamping saluran pencernaan. Beberapa contoh penyakit yang disebabkan oleh bakteri patogen asal pangan ialah gagal ginjal, keguguran kandungan, dan kematian bayi lahir (stillbirth).

Hasil penelitian terdahulu (5) berhasil mengisolasi dan mengiden-tifikasi Salmonella dalam daging ayam. Salmonella yang ditemukan dalam daging ayam sebanyak 6 serotipe yaitu $S$. schwarzengrund, $S$. kentucky, S. anatum, S. agona, S. hadar dan
S. typhimurium. Selain dari sampel ayam, Salmonella juga ditemukan pada daging sapi dan babi ${ }^{(6,7)}$. Bakteri patogen Salmonella yang juga berbahaya dan pernah diisolasi oleh Andini $\mathrm{dkk}^{(8)}$ ialah Listeria monocytogenes dan ditemukan pada daging sapi, ayam dan babi. Bakteri ini dapat hidup dan berkembang biak pada suhu rendah $4^{\circ} \mathrm{C}$. Nilai $\mathrm{D}_{10}$ Salmonella bervariasi antara 0,5 1,0 kGy, sedang L. monocytogenes bervariasi antara $1,1-1,5 \mathrm{kGy}^{(9)}$. Hasil penelitian Effendi dan Arvina yang dikutip dari Iwantoro $^{(3)}$ mendapatkan hampir semua jenis sayuran lokal mengandung residu pestisida dan beberapa diantaranya mengandung lebih dari satu jenis. Hasil uji Lab. Departemen Pertanian pada tahun 2003, residu pestisida pada sayuran lokal dibawah Batas Maksimum Residu (BMR). Menurut Enie ${ }^{(2)}$, penyakit yang disebabkan oleh makanan selain bakteri adalah cemaran logam berat, pestisida dan bahaya kimia lainnya. Pengaruh pencemaran lingkungan pada kualitas dan keamanan pangan telah lama diteliti diberbagai kawasan di dunia termasuk Indonesia. Telah diketahui bahwa kandungan logam berat seperti air raksa $(\mathrm{Hg})$, kadmium $(\mathrm{Cd})$, timbal $(\mathrm{Pb})$ dan lain-lain dapat merusak reproduksi, anemi dan lain-lain ${ }^{(10,11)}$.

Tujuan penelian ini untuk mengetahui kontaminasi bakteri seperti koliform, Salmonella, Staphylococcus, residu insektisida organofosfat dan kandungan logam berat yang terkandung dalam sayuran yang dijual di pasar tradisional dan swalayan.

\section{BAHAN DAN METODE}

Bahan. Sayuran yang digunakan pada penelitian ini dibeli dari pasar tradisional 
maupun swalayan di Jakarta. Jumlah sampel yang diteliti setiap kali pengambilan contoh adalah sebanyak 3 kali.Penentuan Jumlah Total Bakteri. Penentuan jumlah total bakteri dilakukan dengan cara menimbang sampel sebanyak 25 g kemudian dicampur dengan $225 \mathrm{ml}$ air pepton steril dan selanjutnya dilakukan pengenceran bertingkat. Sejumlah $0,1 \mathrm{ml}$ larutan suspensi ditanam dalam media lempeng cawan petri yang berisi Agar Nutrien (Oxoid) dan dieram pada suhu kamar selama 24-48 jam. Penentuan Jumlah Bakteri Koli. Penentuan jumlah bakteri koli dilakukan seperti pada penentuan jumlah total bakteri. Media yang digunakan ialah Agar Mac Conkey (Oxoid) dan dieram pada suhu $37^{\circ} \mathrm{C}$ selama 24-48 jam. Penentuan Jumlah Bakteri Staphylococcus. Penentuan jumlah bakteri Staphylococcus dilakukan seperti pada penentuan jumlah total bakteri. Media yang digunakan ialah Baird Parker Agar (Oxoid) dan dieram pada suhu $37^{\circ} \mathrm{C}$ selama $24-48$ jam. Pemeriksaan Salmonella. Pemeriksaan Salmonella dilakukan dengan cara sampel ditimbang sebanyak $25 \mathrm{~g}$ kemudian ditanam dalam media pengaya dan dieram pada suhu $37^{\circ} \mathrm{C}$ selama 24 jam dan selanjutnya ditanam pada media selektif yang dieram pada suhu $37^{\circ} \mathrm{C}$ selama 48 jam. Koloni tersangka diidentifikasi secara mikrobiologi dan biokimia ke arah Salmonella dan dilanjutkan dengan uji serologi untuk ditentukan serotipe seperti pada prosedur yang dilakukan oleh Andini dkk ${ }^{(2)}$ dan Sri Poernomo ${ }^{(12)}$.

Penentuan Residu Pestisida. Penentuan residu pestisida dilakukan seperti pada prosedur penelitian Sofnie (13). Penentuan Logam Berat. Penentuan logam berat dilakukan seperti pada penelitian Harsojo dkk ${ }^{(14)}$.

\section{HASIL DAN PEMBAHASAN}

Kesadaran masyarakat akan keamanan pangan perlu ditunjang dengan pe-mahaman akan sanitasi sehingga pengolahan sayuran ditingkat rumah tangga akan lebih aman yang memenuhi syarat kesehatan. Membiasakan meng-konsumsi sayuran mentah sebagai lalap masih mempunyai resiko yang cukup berbahaya yaitu dengan tingginya pencemaran mikroba yang ditemukan pada sayuran lalap.

Hal ini dapat terlihat pada Tabel 1. Pada Tabel tersebut disajikan jumlah total bakteri aerob tertinggi yang didapatkan masing-masing pada kacang panjang, dan kubis untuk lokasi I, dan II maupun III.

Pada Tabel 1 terlihat jumlah bakteri aerob tertinggi untuk kacang panjang didapatkan pada lokasi I yaitu $3,70 \times 10^{7} \mathrm{cfu} / \mathrm{g}$, sedang terendah didapatkan di lokasi III yaitu 8,40 x $10^{4} \mathrm{cfu} / \mathrm{g}$. Pada ketimun jumlah bakteri aerob tertinggi didapatkan pada lokasi II yaitu 7,00

Table 1. Total bakteri aerob pada beberapa macam sayuran (cfu/g)

\begin{tabular}{|c|c|c|c|}
\hline \multirow{2}{*}{ Sampel } & \multicolumn{3}{|c|}{ Lokasi } \\
\cline { 2 - 4 } & I & II & III \\
\hline Kacang panjang & $3,70 \times 107$ & $9,00 \times 105$ & $8,40 \times 104$ \\
\hline Ketimun & $3,50 \times 104$ & $7,00 \times 105$ & $2,27 \times 105$ \\
\hline Kubis & $4,00 \times 105$ & $2,88 \times 107$ & $1,87 \times 106$ \\
\hline Kemangi & $1,15 \times 107$ & $2,45 \times 107$ & $4,90 \times 107$ \\
\hline
\end{tabular}


x $10^{5} \mathrm{cfu} / \mathrm{g}$, dan terendah didapatkan pada lokasi I yaitu $3,50 \times 10^{4} \mathrm{cfu} / \mathrm{g}$. Sayuran kubis jumlah bakteri aerob tertinggi didapatkan pada lokasi II yaitu $2,88 \times 10^{7} \mathrm{cfu} / \mathrm{g}$ dan terendah di lokasi I yaitu $4,00 \times 10^{5} \mathrm{cfu} / \mathrm{g}$. Jumlah bakteri aerob tertinggi pada kemangi didapatkan pada lokasi III yaitu 4,90 x $10^{7} \mathrm{cfu} / \mathrm{g}$ dan terendah didapatkan pada lokasi I yaitu $1,15 \times 10^{7} \mathrm{cfu} / \mathrm{g}$. Tingginya kontaminasi bakteri aerob pada sayuran lalap mungkin berasal dari tempat sayuran tersebut ditanam. Selama penanaman air siraman yang digunakan mungkin berasal dari air yang telah tercemar kemudian setelah dipanen sayuran tersebut masih disiram supaya tampak segar. Selanjutnya selama pengangkutan ke pasar dan tempat penjualan sayur kurang memperhatikan sanitasi tempat penyimpanan. Umumnya petani maupun pedagang belum banyak yang menerapkan Sistem Manajemen Keamanan Pangan.

Pada Tabel 2 disajikan jumlah bakteri koli pada beberapa macam sayuran lalab dari beberapa lokasi. Kandungan bakteri koli tertinggi didapatkan pada sayuran berupa kacang panjang dan kemangi pada lokasi I, sedang pada lokasi II adalah kemangi. Pada Lokasi III kandungan bakteri koli tertinggi juga didapatkan pada kemangi.

Pada lokasi III tidak ditemukan bakteri koli pada kacang panjang, sedang pada lokasi lainnya (I dan II) ditemukan bakteri koli masing-masing dengan jumlah $1,49 \times 10^{7}$ dan $1,11 \times 10^{5} \mathrm{cfu} / \mathrm{g}$. Pada ketimun kontaminasi bakteri koli terendah didaptkan pada lokasi I yaitu $1,06 \times 10^{4} \mathrm{cfu} / \mathrm{g}$ dan tertinggi pada lokasi II yaitu $1,72 \times 10^{5} \mathrm{cfu} / \mathrm{g}$. Bakteri koli tidak ditemukan untuk sayuran kubis pada lokasi III, akan tetapi pada lokasi I dan II ditemukan bakteri koli yaitu masingmasing $6,50 \times 10^{4}$ dan $3,40 \times 10^{6} \mathrm{cfu} / \mathrm{g}$. Pada kemangi pertumbuhan bakteri koli terendah ditemukan pada lokasi I yaitu $1,43 \times 10^{6}$ cfu/g dan tertinggi didapatkan pada lokasi

Table 2. Total bakteri koli pada beberapa macam sayuran (cfu/g)

\begin{tabular}{|c|c|c|c|}
\hline \multirow{2}{*}{ Sampel } & \multicolumn{3}{|c|}{ Lokasi } \\
\cline { 2 - 4 } & I & II & III \\
\hline Kacang panjang & $1,49 \times 107$ & $1,11 \times 105$ & - \\
\hline Ketimun & $1,06 \times 104$ & $1,72 \times 105$ & $7,10 \times 104$ \\
\hline Kubis & $6,50 \times 104$ & $3,40 \times 106$ & - \\
\hline Kemangi & $1,43 \times 106$ & $9,30 \times 106$ & $9,20 \times 106$ \\
\hline
\end{tabular}

$(-)=$ tidak tumbuh

Table 3. Total Staphylococcus pada beberapa macam sayuran (cfu/g)

\begin{tabular}{|c|c|c|c|}
\hline \multirow{2}{*}{ Sampel } & \multicolumn{3}{|c|}{ Lokasi } \\
\cline { 2 - 4 } & $\mathrm{I}$ & $\mathrm{II}$ & III \\
\hline Kacang panjang & $1,50 \times 104$ & $8,50 \times 103$ & $11,0 \times 102$ \\
\hline Ketimun & - & $3,00 \times 103$ & $3,20 \times 103$ \\
\hline Kubis & $2,20 \times 103$ & $2,00 \times 105$ & $3,00 \times 102$ \\
\hline Kemangi & $4,00 \times 104$ & $7,80 \times 104$ & $1,29 \times 105$ \\
\hline
\end{tabular}

$(-)=$ tidak ada pertumbuhan. 
II yaitu 9,30 x $10^{6} \mathrm{cfu} / \mathrm{g}$. Tingginya cemaran bakteri koli mungkin karena air yang digunakan untuk menyiram tanaman tersebut telah tercemar bakteri koli atau kemungkinan sumber air tersebut terlalu dekat septic tank. Jumlah bakteri Staphylococcus pada beberapa macam sayuran disajikan pada Tabel 3. Pada Tabel 3 terlihat bahwa untuk lokasi I kandungan Staphylococcus tertinggi didapatkan pada kacang panjang. Pada lokasi II kandungan tertinggi didapatkan pada kubis untuk lokasi III didapatkan pada kemangi.

Pada semua sayuran yang diteliti dari lokasi I, II dan III tidak ditemukan adanya bakteri Salmonella. Tabel 4 menyajikan residu insektisida dalam sayuran. Pada Tabel tersebut terlihat secara umum di lokasi I, II maupun III hampir semua sayuran tidak mengandung residu insektisida. Akan tetapi pada sayuran kacang panjang yang berasal dari lokasi III ditemukan adanya residu insektisida diazinon. Adanya residu tersebut kemungkinan berasal dari air yang digunakan untuk menyiram sayuran yang telah terkontaminasi insektisida. Kemungkinan lainnya adalah petani juga menggunakan insektisida untuk menjaga sayurannya tidak diserang hama. Residu insektisida diazinon yang terkandung dalam kacang panjang telah melebihi ambang batas yang diizinkan.

Unsur-unsur logam berat sampai pada tingkat konsentrasi tertentu masih dibutuhkan sebagai mikro elemen dalam proses metabolisme dan bila kekurangan logam berat akan terjadi defisiensi (15). Menurut Hutagalung (15), toksisitas logam berat dipengaruhi oleh $\mathrm{pH}$,

Table 4. Residu insektisida organophosphat pada beberapa macam sayuran (ppm).

\begin{tabular}{|c|c|c|c|c|c|c|c|c|c|}
\hline \multirow[b]{2}{*}{ Lokasi } & \multirow[b]{2}{*}{ Sampel } & \multicolumn{8}{|c|}{ Residu insektisida organophosphat (ppm) } \\
\hline & & $\begin{array}{c}\text { Dia } \\
\text { zinon }\end{array}$ & $\begin{array}{l}\text { Klor } \\
\text { pyri } \\
\text { phos }\end{array}$ & $\begin{array}{c}\text { Profeno } \\
\text { fos }\end{array}$ & $\begin{array}{l}\text { Mala } \\
\text { thion }\end{array}$ & $\begin{array}{c}\text { Metida } \\
\text { thion }\end{array}$ & $\begin{array}{c}\text { Protio } \\
\text { phos }\end{array}$ & $\begin{array}{c}\text { Triazo } \\
\text { phos }\end{array}$ & $\begin{array}{c}\text { Fenitro } \\
\text { thion }\end{array}$ \\
\hline \multirow{4}{*}{ I } & $\begin{array}{l}\text { Kacang } \\
\text { panjang }\end{array}$ & ttd & ttd & ttd & ttd & ttd & ttd & ttd & ttd \\
\hline & Ketimun & ttd & $\mathrm{ttd}$ & $\mathrm{ttd}$ & $\mathrm{ttd}$ & $\mathrm{ttd}$ & $\mathrm{ttd}$ & $\mathrm{ttd}$ & $\mathrm{ttd}$ \\
\hline & Kubis & ted & $\mathrm{ttd}$ & $\mathrm{ttd}$ & $\mathrm{ttd}$ & $\mathrm{ttd}$ & $\mathrm{ttd}$ & $\mathrm{ttd}$ & $\mathrm{ttd}$ \\
\hline & Kemangi & & $\mathrm{ttd}$ & $\mathrm{ttd}$ & $\mathrm{ttd}$ & $\mathrm{ttd}$ & $\mathrm{ttd}$ & $\mathrm{ttd}$ & $\operatorname{ttd}$ \\
\hline \multirow{4}{*}{ ॥I } & $\begin{array}{l}\text { Kacang } \\
\text { panjang }\end{array}$ & ttd & $\mathrm{ttd}$ & $\mathrm{ttd}$ & $\mathrm{ttd}$ & $\mathrm{ttd}$ & $\mathrm{ttd}$ & $\mathrm{ttd}$ & $\mathrm{ttd}$ \\
\hline & Ketimun & ttd & $\mathrm{ttd}$ & ttd & $\operatorname{ttd}$ & $\operatorname{ttd}$ & ttd & ttd & ttd \\
\hline & Kubis & ttd & $\mathrm{ttd}$ & $\operatorname{ttd}$ & $\mathrm{ttd}$ & $\mathrm{ttd}$ & $\mathrm{ttd}$ & $\mathrm{ttd}$ & $\mathrm{ttd}$ \\
\hline & Kemangi & $\mathrm{ttd}$ & $\mathrm{ttd}$ & $\mathrm{ttd}$ & $\mathrm{ttd}$ & $\mathrm{ttd}$ & $\mathrm{ttd}$ & $\mathrm{ttd}$ & ttd \\
\hline \multirow{4}{*}{ III } & $\begin{array}{l}\text { Kacang } \\
\text { panjang }\end{array}$ & 4,32 & $\mathrm{ttd}$ & ttd & $\mathrm{ttd}$ & ttd & $\mathrm{ttd}$ & ttd & ttd \\
\hline & Ketimun & $\mathrm{ttd}$ & ttd & ttd & ttd & $\mathrm{ttd}$ & $\mathrm{ttd}$ & $\mathrm{ttd}$ & $\mathrm{ttd}$ \\
\hline & Kubis & $\operatorname{ttd}$ & $\mathrm{ttd}$ & $\operatorname{ttd}$ & $\mathrm{ttd}$ & $\mathrm{ttd}$ & $\mathrm{ttd}$ & $\mathrm{ttd}$ & $\mathrm{ttd}$ \\
\hline & Kemangi & ttd & ttd & ttd & $\mathrm{ttd}$ & ttd & ttd & $\mathrm{ttd}$ & $\mathrm{ttd}$ \\
\hline \multicolumn{2}{|c|}{$\begin{array}{l}\text { Limit detection } \\
(\mathrm{ppm})\end{array}$} & 0.015 & 0.050 & 0.040 & 0.016 & 0.080 & 0.025 & 0.025 & 0.040 \\
\hline
\end{tabular}


Table 5. Kandungan logam berat pada beberapa macam sayuran(ppm)

\begin{tabular}{|c|c|c|c|}
\hline \multirow{2}{*}{ Sampel } & \multicolumn{3}{|c|}{ Lokasi } \\
\cline { 2 - 4 } & $\mathrm{Pb}$ & $\mathrm{Hg}$ & $\mathrm{Cd}$ \\
\hline Kacang panjang & - & 0,014 & 0,022 \\
\hline Ketimun & - & 0,028 & 0,023 \\
\hline Kubis & - & 0,019 & 0,021 \\
\hline Kemangi & - & 0,026 & 0,053 \\
\hline
\end{tabular}

$(-)=$ tidak terdeteksi.

suhu, efek sinergetik dari beberapa logam. Unsur logam berat tersebut dapat masuk ke dalam tubuh melalui ransum makanan. Logam berat air raksa $(\mathrm{Hg})$ dan turunannya sangat beracun dan dapat terakumulasi sehingga dapat merusak atau menstimulasi sistim enzimatik.

Tabel 5 menyajikan kandungan logam berat pada beberapa macam sayuran. Kandungan timah hitam tidak didapatkan pada semua macam sayuran yang diperiksa. Timah hitam tersebut cukup berbahaya bila di dalam makanan/sayuran melebihi ambang batas karena dapat mengganggu sistem reproduksi juga bersifat neurotoksin (beracun terhadap saraf). Pada anak-anak akan menyebabkan turunnya tingkat kecerdasan. Disamping itu dapat meningkatkan kasus infeksi saluran pernafasan atas, tekanan darah, memicu serangan jantung, merusak ginjal dan pada akhirnya menimbulkan kematian (16). Kandungan raksa pada sayuran bervariasi antara 0,014 dan 0,028 ppm. Kandungan raksa tertinggi didapatkan pada ketimun dan terendah pada kacang panjang. Dampak dari logam berat raksa akan menyebabkan berat badan lahir rendah dan meningkatkan angka kematian bayi, serta efek teratogenik berupa kerusakan khromosom ${ }^{(10)}$. Kandungan kadmium pada sayuran bervariasi antara 0,021 dan 0,053 ppm. Kandungan kadmium tertinggi didapatkan pada kemangi dan terendah didapatkan pada kubis. Dampak dari kandungan kadmium yang melebihi ambang batas adalah dapat menimbulkan kanker prostat ${ }^{(10)}$. Tingginya kandungan logam berat dalam sayuran kemungkinan berasal dari pupuk yang digunakan, tanah pertanian tempat sayuran ditanam dan air yang digunakan untuk menyiram tanaman. Variasi kandungan logam berat pada sayuran dimungkinkan juga karena tempat penanaman sayur berada di berbagai tanah pertanian. Walaupun demikian logam berat air raksa dan kadmium pada semua macam sayuran masih di bawah ambang batas yang diizinkan.

\section{KESIMPULAN}

- Sayuran yang dijual di lokasi I dan II mengandung jumlah bakteri aerob dan bakteri koli tertinggi dibandingkan dengan lokasi III.

- Kacang panjang di lokasi III tidak memenuhi persyaratan ambang batas residu insektisida yang diizinkan.

- Kandungan logam berat pada sayuran masih di bawah ambang batas yang diizinkan. 


\section{UCAPAN TERIMA KASIH}

Ucapan terima kasih penulis ucapkan kepada Dra. Suwirma S., sdr. Anastasia S.D., sdr. Maryoto dan sdr. Elida Djabir atas bantuannya sehingga penelitian ini dapat berjalan dengan lancar.

\section{DAFTAR PUSTAKA}

1. R.D., Hariyadi. 2002. Keracunan pangan tak hanya sebabkan diare, Harian Kompas, 15 Desember. 32.

2. A.B. Enie. 2003. Mikrobiologi pangan, standar pangan dan keamanan pangan dalam menghadapi era perdagangan global, dibawakan pada "DIPA-OXOID Microbiology Seminar, Jakarta, 21 Oktober.

3. S., Iwantoro. 2004. Kebijakan sertifikasi mutu dan keamanan pangan segar, dibawakan pada Workshop Nasional Tuntutan pasar Global, Kredibilitas Laboratorium Uji dan Sertifikasi, Jakarta, 16 September.

4. Sri Poernomo, 1995. Standar higiene dan keamanan pangan, Bahan Penataran Manajemen Usaha Jasa Boga di IPB, Bogor.

5. L.S.Andini, Harsojo, Anastasia, S.D. dan Maha, M. 1994. Isolasi dan identifikasi Salmonella dari daging ayam segar, Ris. APISORA PAIR-BATAN, 165-171.

6. L.S. Andini, Harsojo, dan Rosalina, S.H. 1995. Dekontaminasi bakteri patogen Salmonella dengan iradiasi gamma, Pros. Sem. Nas. Peternakan dan Veteriner, Bogor, 897-902

7. Harsojo, Erma, Andini, L.S., dan Rosalina, S.H. 1997. Eliminasi bakteri Salmonella dan koli pada daging dan jerohan dan dekon-taminasinya dengan iradiasi gamma, Pros. Sem. Nas. Biol. XV, UNILA Lampung, 1580-1584.

8. L.S. Andini, Harsojo, dan Rosalina,
S.H.. 1998. Kemampuan hidup Listeria onocytogenes yang diisolasi dari bahan pangan asal ternak terhadap iradiasi gamma, Pros. Sem. Hasil-Hasil Penelitian Veteriner, 95-102.

9. L.S. Andini. 1995. Pertumbuhan optimal bakteri patogen Salmonella dan dekontami nasinya pada daging ayam dengan iradiasi gamma, Presentasi Ilmiah Jabatan Peneliti PAIR-BATAN.

10. Anonim. 1998. Pencemaran bisa merusak reproduksi, Harian KOMPAS 21 Desember 20.

11. Darmono. 1995. Logam dalam sistem biologi makhluk hidup, Penerbit Univ. Indonesia.

12. Sri Poernomo. 1994. Salmonella pada ayam di rumah potong dan lingkungannya di Wilayah Jakarta dan sekitarnya, Sem. Nas. Teknologi Veteriner untuk Meningkatkan Kesehatan Hewan dan Pengamanan Bahan Pangan Asal Ternak, Balitvet, Bogor, 338-345.

12. C.M. Sofnie, 2006. Pengaruh pencucian dan pemasakan terhadap residu insektisida klorpirifos pada wortel (Daucus carota L.), Gakuryoku XII 1, 26-30.

13. Harsojo, Andini L.S., Rosalina S.H. dan Suwirma S. 2000. Limbah agroindustri dan peternakan ayam sebagai pakan tambahan ikan nila, Ris. Pertemuan Ilmiah Penelitian dan Pengembangan Teknologi Isotop dan Radiasi, BATAN, Puslitbang Tekonologi dan Radiasi, 175180.

14. H.P. Hutagalung. 1991. Pencemaran laut oleh logam berat dan petunjuk praktek logam berat, Bahan Kursus Pemantauan Pencemaran Laut IV LIPI UNESCOUNDP, Jakarta 15 Februari - 21 Maret.

15. Anonim, 2000. Timah hitam memang berbahaya, Harian KOMPAS 27 Februari 